\title{
Seasonal Abundance, Grazing Impacts on Bacteria, and Vertical Distribution of Heterotrophic Microflagellates in the South Basin of Lake Biwa*
}

\author{
Toshi NagATA
}

\begin{abstract}
Seasonal abundance of heterotrophic microflagellates and bacteria was investigated at an offshore station (water depth, $c a .4 \mathrm{~m}$ ) in the south basin of Lake Biwa (eutrophic water basin) during May to October 1984. Cell abundance of flagellates and bacteria ranged from $1.7 \times 10^{3}$ to $9.7 \times 10^{3}$ cells $\cdot \mathrm{ml}^{-1}$ and $2.5 \times 10^{6}$ to $1.5 \times 10^{7}$ cells $\cdot \mathrm{ml}^{-1}$, respectively. The instantaneous grazing rate $(g)$ of flagellates on bacteria was estimated from the total cell volume of flagellates and the volume specific clearance rate of flagellates reported in the literature. The $g$ values ranged from 0.003 to $0.020 \mathrm{~h}^{1}$. The instantaneous growth rate $(\mu)$ of bacteria estimated from the frequency of dividing cells method ranged from 0.009 to $0.034 \mathrm{~h}^{-1}$. From the values of $g$ and $\mu$, it was estimated that $13-130 \%$ of bacterial daily production was consumed by flagellates. Vertical distribution of flagellates at the dredged area (water depth, $c a .12 \mathrm{~m}$ ) of the same water basin revealed that flagellates reached maximum abundance in a subsurface layer ( $6 \mathrm{~m}$-depth) during the stratification. The significance of flagellates as bacterial consumers and some characteristics of their occurrence in the eutrophic water body are discussed.
\end{abstract}

Key words : grazing impact, heterotrophic microflagellates, Lake Biwa, planktonic bacteria

\section{Introduction}

It has been suggested that heterotrophic microflagellates are significant consumers of planktonic bacteria in seas (Fenchel, 1982c; Sinburth and DAIIs, 1982 ; Sherr et al., 1984), estuaries (WricinT and Coffis, 1984) and lakes (GÜDE, 1986 ; SCAliA and LAIRI), 1987 ; NA(iATA, 1988). However, little is known about the abundance, grazing impacts on bacteria, and distribution of flagellates in eutrophic lakes (RIF.MANiN, 1985).

From the enclusure experiments conducted in eutrophic Slottss $\varnothing$, Denmark, Riknaxi (1985) found that the abundance of flagellates is markedly influenced by the population density of macrozooplankters $(>140 \mu \mathrm{m})$ in the enclosures. He observed that the cell densities of flagellates in the enclosures that included dense macrozooplankters were only 1 to $7 \%$ of those found in the other enclosures with few macrozooplankters. He also calculated the grazing rate of flagellates, and suggested the significant grazing impacts on bacteria in the enclosures with many flagellates. In Lake Oglethorpe, SANDERS and PoRTER (1986) assessed grazing rate of protozoans on bacteria by the antibiotics method. They estimated that protozoans consume $60-80 \%$ of epilimnetic bacterial standing crop per day. PEIJRós-Alió and BRock (1982), on the other hand, assumed that grazing by flagellates is negligible for the consideration of the loss factor of epilimnetic bacteria in eutrophic Lake Mendota.

In the present study, seasonal abundance of heterotrophic microflagellates was examined at a sampling station located in a eutrophic, shallow water basin of Lake Biwa (the south basin), and grazing impacts of flagellates on bacteria were assessed. Vertical distribution of flagellates at the dredged area of the same basin was also investigated. Some characteristics of the occurrence of 
flagellates in this basin are compared with the results previously obtained in the north basin of Lake Biwa, a mesotrophic, deep water body (NAciATA, 1987, 1988).

\section{Study site}

The south basin of Lake Biwa (Fig. 1) is a eutrophic shallow water basin (surface area, 57 $\mathrm{km}^{2}$, mean water depth, $3.5 \mathrm{~m}$ ). Recent trophic state (TњzlKA, 1984) and bacterial level (NAGATA, 1984) of this lake have been described. One sampling station (St. Nb5, depth ca. $4 \mathrm{~m}$ ) for the seasonal investigation was located in the center of this basin, while the other sampling station (St. D, water depth $(a .12 \mathrm{~m}$ ) for the examination of vertical distribution was located in the dredged area $(500 \mathrm{~m} \times 500 \mathrm{~m})$. Details of the location. morphometry and water quality of this area have been described by TERASHIMA and UEIA (1982).

\section{Materials and methods}

Surface water samples were collected at St. Nb5 between 14 May and 24 October 1984. At St. D.

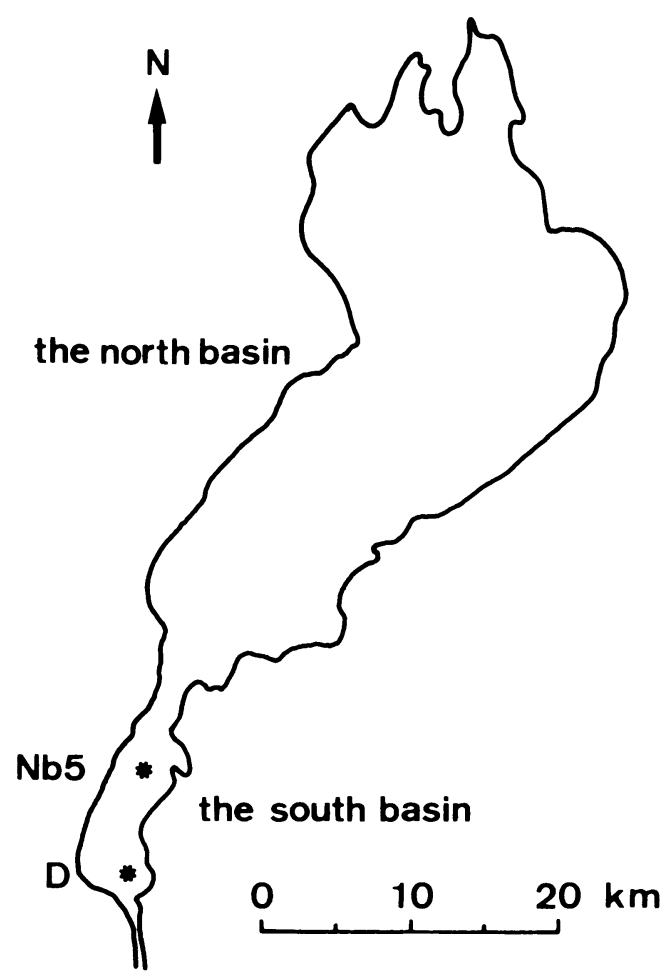

Fig. 1. Two sampling stations in Lake Biwa (Nb5 and D). samples were collected vertically by a 3-liter Van Dorn water sampler on 9 August, 18 September, and 12 October 1984. Samples for bacteria were fixed with $2 \%$ formalin (final conc.), but with $1 \%$ glutaraldehyde (final conc.) for flagellates. The samples were kept cool until they were processed (up to 3 weeks). Bacteria were enumerated by the acridine orange direct count method (HoBBIE et al., 1977 ; NAGATA, 1984), while heterotrophic microflagellates were enumerated by epifluorescence microscopy using fluorescein isothiocyanate (Sherr and Sherr, 1983 ; Naciata, 1986b). Two filters were used for each sample, and the range of the duplicates was $2-41 \%$ (mean 13 ) of the mean value for bacteria and $0-48 \%$ (mean 15) for flagellates. Details of the procedures for counting bacteria and flagellates have been described elsewhere (NAciata, 1988). Bacteria and flagellates were sized with an ocular micrometer $(\times 1,250)$. For each sample, 20 cells were measured for bacteria 1, and 43-123 cells (mean 79) for flagellates. Cell volume was estimated assuming the shape of bacteria to be spherical or cylindrical with hemispherical ends, and that of flagellates to be spherical or ellipsoidal. Carbon biomass was estimated using a conversion factor of $108 \mathrm{fg} \mathrm{C}$. $\mu \mathrm{m}^{-3}$ for bacteria (NAciATA, 1986a), and $71 \mathrm{fg} \mathrm{C}$. $\mu \mathrm{m}^{-3}$ for flagellates (FENCHEL and FINLAY, 1983). The frequency of dividing cells (FDC) of bacteria was determined according to HAGsTRöM et al. (1979).

Grazing impact of flagellates on bacteria was assessed by comparing the instantaneous growth rate of bacteria with the instantaneous grazing rate of flagellates on bacteria. The instantaneous grazing rate was calculated from total cell volume (cell abundance multiplied by mean cell volume) of flagellates. The assumptions of this method are that flagellates can, in an hour, clear bacteria from a volume of water that is $10^{5}$ times their own cell volume at $20^{\circ} \mathrm{C}$ (FENCHEL, 1982b) and that $Q_{10}$ of the clearance rate is 2 (FENchel, 1987). The instantaneous growth rate of bacteria was estimated by the FDC method (HAciström et al., 1979). The FDC-growth rate calibration equation derived for the north basin of Lake Biwa (NA(;ATA, 1987) was used for the calculation.

Chlorophyll a concentration was measured spectrofluorometrically (STRICKLANI) and PARSONS, 1972). Dissolved oxygen concentration was measured by the Winkler method. 


\section{Results}

At St. Nb5, cell abundance of heterotrophic flagellates ranged from $1.7 \times 10^{3}$ to $9.7 \times 10^{3}$ cells . $\mathrm{ml}^{-1}$ (Fig. 2). Although no quantitative estimation was undertaken, the flagellates were commonly unattached forms. More than $70 \%$ of flagellates were 2 to $4 \mu \mathrm{m}$ in terms of equivalent spherical diameter (Fig. 3). Mean cell volume for each sample ranged from 9 to $35 \mu \mathrm{m}^{3}$ (mean 21) (data not shown). From the cell abundance and the mean cell volume, the biomass of flagellates was estimated to be $2.4-13 \mu \mathrm{g} \mathrm{C} \cdot 1^{-1}$ (Fig. 2).

The range of bacterial abundance was from $2.5 \times$ $10^{6}$ to $1.5 \times 10^{7}$ cells $\cdot \mathrm{ml}^{-1}$ (Fig. 2). Contribution of attached bacteria in cell number ranged from 0 (not detected) to $21 \%$ (mean 6.6) (data not shown). Mean cell volume of bacteria calculatd for the whole samples was $0.095 \mu \mathrm{m}^{3}(\mathrm{n}=300, \mathrm{SD}=0.080)$. Using this mean volume, the bacterial biomass was

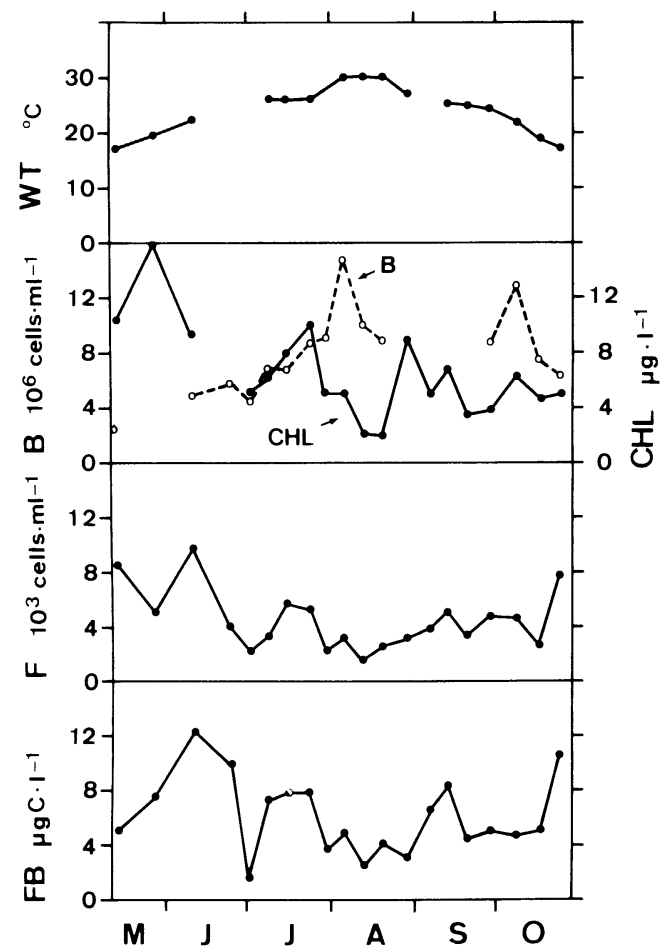

Fig. 2. Seasonal variations of water temperature (WT), chlorophyll a concentration (CHL), bacterial abundance (B), abundance of heterotrophic microflagellates (F), and carbon biomass of heterotrophic microflagellates (FB) at Station Nb5 (surface water).

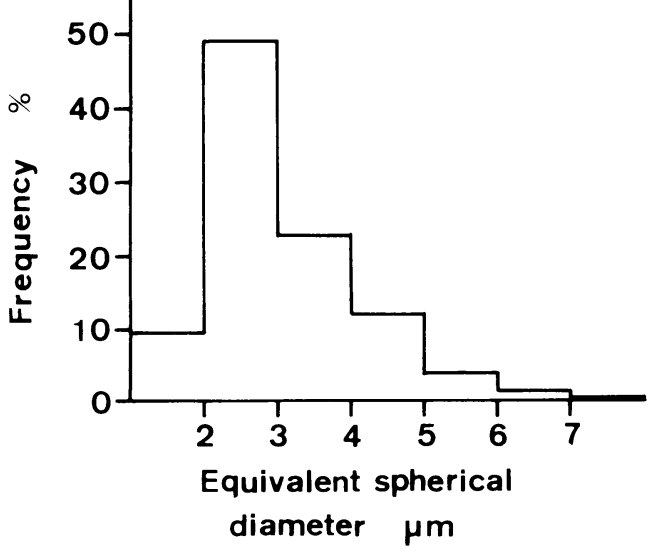

Fig. 3. Size frequency distribution of heterotrophic microflagellates. Samples were collected at Station Nb5 during 14 May to 24 (October 1984. Total number of sized cell was 1580 .

estimated to be $25150 \mu \mathrm{g} C \cdot 1{ }^{1}$. and the biomass of flagellates corresponded to $226 \%$ (mean 10 ) of the bacterial biomass.

To assess the factors that possibly control the variables for flagellates (i.e.. cell abundance, mean cell volume and biomass), simple linear correlations $(r)$ between the variables for flagellates and those for environments (i.e., bacterial abundance. water temperature and chlorophyll a concentration) were calculated. But no significant $(\mathrm{P}<$ (0.05) correlation was found between these variables except in two cases, i.e., between the abundance of flagellates and water temperature $(r=-0.62)$, and between the abundance of flagellates and chlorophyll $a$ concentration $(r=0.49)$.

The instantaneous grazing rate of flagellates ranged from 0.006 to $0.017 \mathrm{hr}^{-1}$, and the instantaneous growth rate of bacteria ranged from 0.010 to $0.034 \mathrm{hr}^{-1}$ (Table 1). It can be suggested that grazing impacts of flagellates on bacteria were significant, because the grazing rate corresponded to $13-130 \%$ of the growth rate (Table 1 ).

On 9 August and 18 September, the water column at St. D was thermally stratified and oxygen depleted below $8 \mathrm{~m}$ (August) and $10 \mathrm{~m}$ (September) (Fig. 4). In these circumstances, highest density of flagellates was found at $6 \mathrm{~m}$, and bacteria was more abundant in the upper 6-m layer than in the lower layer. Vertical variation in abundance was more pronounced for flagellates than for bacteria. Mean cell volume of flagellates 
Table 1. Instantaneous growth rate $(\mu)$ of bacteria and instantaneous grazing rate $(\mathrm{g})$ of heterotrophic microflagellates in the south basin of Lake Biwa (Station Nb5 ; samples were obtained in 1984).

\begin{tabular}{|c|c|c|c|c|c|}
\hline & $\begin{array}{c}\text { Bacterial } \\
\text { abundance } \\
\left(10^{6} \text { cells } \cdot \mathrm{ml}^{-1}\right)\end{array}$ & $\begin{array}{l}\text { Frequency of } \\
\text { dividing cells } \\
(\text { FDC ; \%) }\end{array}$ & $\begin{array}{c}\mu^{(1)} \\
\left(\mathrm{hr}^{-1}\right)\end{array}$ & $\begin{array}{c}\mathrm{g}^{(2)} \\
\left(\mathrm{hr}^{-1}\right)\end{array}$ & $\begin{array}{l}\mathrm{g} / \mu \\
(\%)\end{array}$ \\
\hline 14 May & 2.5 & 2.9 & 0.013 & 0.006 & 46 \\
\hline 11 June & 4.8 & 4.8 & 0.024 & 0.020 & 83 \\
\hline 25 June & 5.7 & 3.3 & 0.015 & 0.018 & 120 \\
\hline 2 July & 4.7 & 4.8 & 0.024 & 0.003 & 13 \\
\hline 9 July & 6.8 & 5.8 & 0.034 & 0.016 & 47 \\
\hline 16 July & 7.1 & 4.3 & 0.021 & 0.017 & 81 \\
\hline 24 July & 8.6 & 3.1 & 0.014 & 0.017 & 121 \\
\hline 30 July & 9.1 & 5.6 & 0.032 & 0.009 & 28 \\
\hline 6 August & 15 & 2.7 & 0.012 & 0.014 & 117 \\
\hline 13 August & 11 & 2.2 & 0.010 & 0.007 & 70 \\
\hline 20 August & 8.8 & 2.6 & 0.012 & 0.012 & 100 \\
\hline 28 September & 8.7 & 2.8 & 0.013 & 0.009 & 69 \\
\hline 8 October & 13 & 2.3 & 0.011 & 0.008 & 73 \\
\hline 17 October & 7.6 & 4.2 & 0.020 & 0.007 & 35 \\
\hline 24 October & 6.3 & 1.9 & 0.009 & 0.012 & 133 \\
\hline
\end{tabular}

(1) $\mu$ was estimated from FDC using the calibration equation; ln $\mu=0.33$ FDC-5.3 (NAciATA, 1987).

(2) $\mathrm{g}$ was estimated from biomass of flagellates assuming that a flagellate clears a water $10^{5}$ times its own cell volume at 20 C (Fenchel, 1982b) and $Q_{10}$ is 2 (Fexchel., 1987).

and bacteria was large in the anoxic layer (Fig. 4) On 12 October, the circulation of the water body was manifest from profiles of water temperature and dissolved oxygen. On this date, flagellates distributed evenly, while bacteria and chlorophyll $a$ showed maxima in a near bottom layer $(11.5 \mathrm{~m})$.

\section{Discussion}

Abundance of flagellates reached $10^{4} \mathrm{cells} \cdot \mathrm{ml}^{-1}$, and that of bacteria reached $10^{7}$ cells $\cdot \mathrm{ml}^{-1}$ in the south basin of Lake Biwa (Figs. 2, 4). These levels are higher than those in the north basin (Table 2). The higher primary production rate, allochthonous organic input, and resuspension of bottom mud in the south basin may well be related to the higher abundance of heterotrophic microbes. However, factors that determine the seasonal dynamics of flagellates and bacteria could not be decided in the present study. Although the correlation analysis indicated that flagellates tend to be more abundant when the water temperature is low and the chlorophyll $a$ is high, the mechanism underlying these correlations is open to further research.

In Lake Biwa, the cell size of bacteria and flagellates is almost the same in the both basins. The mean cell volume $\left[\mu \mathrm{m}^{3}\right]$ of flagellates and bacteria for the south basin was 21 and 0.095 . respectively, while those for the north basin (epilimnion) was 19 and 0.101 , respectively. [The data for the north basin are from NAcita (1988).] A similarity in the mode of heterotrophic microbe existence was also noted between the two basins, i.e. unattached forms of flagellates and bacteria are most common not only in the north basin (NAiATA, 1988) but also in the south basin (see above). This suggests that the prevailing mode of flagellate-bacterial trophic linkage is one between unattached bacteria and flagellates in Lake Biwa. However, in order to ascertain this hypothesis, further measurements of the activity of attached vs. unattached microbes (NAGATA, 1987) is needed for the samples of the south basin.

In the present study, the grazing rate of flagellates on bacteria was calculated from the total cell volume of flagellates. The volume specific clear. ance rate reported in the literature (FExinel, $1982 \mathrm{~b}$ ) was used for this calculation. FExchel (1982b) estimated clearance rates on bacteria by six strains of flagellates (size, 20-200 $\mu \mathrm{m}^{3}$ ), and 


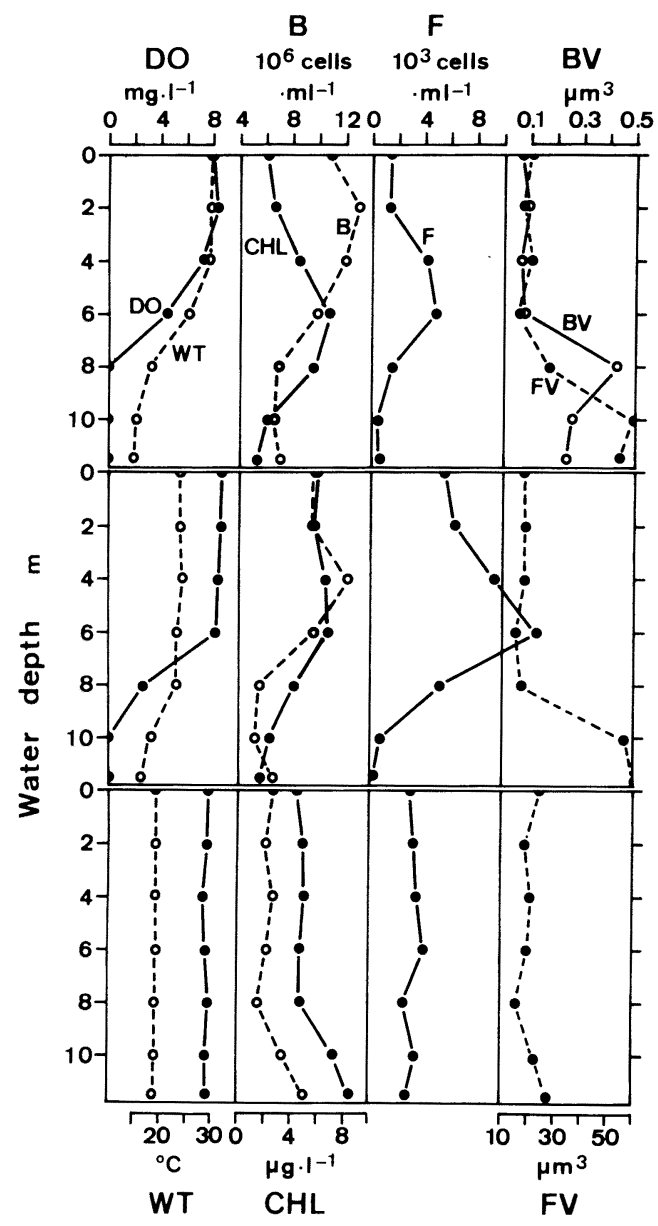

Fig. 4. Vertical distributions of water temperature (WT), dissolved oxygen concentration (DO), chlorophyll $a$ concentration (CHL), bacterial abundance (B), abundance of heterotrophic microflagellates $(\mathrm{F})$, mean cell volume of heterotrophic microflagellates (FV), and mean cell volume of bacteria (BV). Samples were collected at Station D on 9 August 1984 (top panel), 18 September 1984 (middle panel), and 12 October 1984 (bottom panel).

found that they can clear a water $10^{5}$ times (range, $\left.5 \times 10^{4}-1 \times 10^{5}\right)$ their own cell volumes per hour at $20^{\circ} \mathrm{C}$, except for Actinomonas mirabilis, which can filter $10^{6}$ times its cell volume. Since the higher clearance rate of $A$. mirabilis was ascribed to its ability to filter water with a coarse-meshed (1-3.5 $\mu \mathrm{m}$ ) sieving apparatus (Fenchel, 1982a), and it was suggested that this species adapted to collect particles larger than natural bacteria ( $c a .0 .5-1$ $\mu \mathrm{m}$ ) (FENCHEL, 1982b), such a high value would not be suitable for the calculation of the grazing rate on natural planktonic bacteria. SHERr, et al. (1983) also measured the clearance rate on bacteria of Monas sp., and found that volume specific clearance rate of this species was similar to FEnchel's values except for $A$. mirabilis. From the above information, it was assumed that a flagellate cell of Lake Biwa clears water $10^{5}$ times its own cell volume per hour at $20^{\circ} \mathrm{C}$ and $Q_{10}$ is 2 (FENCHel, 1987) in estimating the grazing rate of flagellates. By this method, the grazing rate (number of bacteria $\cdot$ flagellate $\mathrm{e}^{-1} \cdot \mathrm{hr}^{-1}$ ) will be overestimated, if bacterial biomass exceeds the level at which the grazing rate reaches the maximum grazing rate (FENCHEL, 1980). However, the grazing rates calculated in this study (instantaneous grazing rate multiplied by bacterial density) were usually below the maximum grazing rate reported for some strains of small flagellates (27 bacteria $\cdot \mathrm{hr}^{-1}$ for Monosiga sp. [size, $20 \mu \mathrm{m}^{3}$ ]. and 54 bacteria $\cdot \mathrm{hr}^{-1}$ for Pleuromonas jaculans [size, $90 \mu \mathrm{m}^{3}$ ] ; Fenchel, 1982b). Therefore, it was considered that the grazing rate of flagellates may not be overestimated. In the north basin of Lake Biwa, NAGATA (1988) found that grazing rates estimated by this method are cosistent with those derived from bacterial growth in fractionated samples, suggesting the reliability of the method.

From the comparison of the grazing rate of flagellates and growth rate of bacteria (Table 1), it was suggested that a significant fraction (13$130 \%$ ) of bacterial production is consumed by flagellates. These data indicate that flagellates are significant consumers of planktonic bacteria not only in meso- and oligotrophic environments (Sieburth and Davis, 1982 ; Fenchel, 1982c ; Sherr et al., 1984 ; GÜDE, 1986 ; S(AVIA and LAIRI), 1987 ; NAGATA, 1988), but also in shallow eutrophic lake environments. For the consideration of the loss factor of bacteria in eutrophic environments, the grazing of flagellates should be examined. Moreover, the necessity of research on the role of the "microbial loop" (AzA.1 et al., 1983) in the energy transfer and matter cycling within eutrophic lake environments should be stressed. However, the possibility that there are bacterivores other than heterotrophic flagellates in the investigated area must be also noted. Crustaceans (NAGATA, 1985 ; NAGATA and OKAn(oT), 1988), rotifers (BosidaN et al., 1980), ciliates (Sherr and SHerr, 1987), and mixotrophic flagellates (KInURA and 
Table 2. Comparison of the abundance of heterotrophic microflagellates and bacteria between the north basin and the south basin of Lake Biwa ${ }^{(1)}$.

\begin{tabular}{lcccc}
\hline & \multicolumn{2}{c}{ Flagellates $\left(10^{3}\right.$ cells $\left.\bullet \mathrm{ml}^{-1}\right)$} & \multicolumn{2}{c}{ Bacteria $\left(10^{6}\right.$ cells $\left.\mathrm{ml}^{-1}\right)$} \\
& Min-Max & Mean $(\mathrm{C} . \mathrm{V} .)^{(2)}$ & Min-Max & Mean $(\mathrm{C} . V .)^{(2)}$ \\
\hline South basin (St. Nb5) & $1.7-9.7$ & $4.4(50)$ & $2.5^{-15}$ & $8.0(41)$ \\
North basin (St. Ie) & $1.0^{-3}-9$ & $1.9(42)$ & $1.6-6.2$ & $3.9(28)$ \\
\hline
\end{tabular}

(1) Surface water samples were collected during 14 May to 24 October 1984. For flagellates, 20 pairs of data (each pair of the samples was obtained on the same date) were compared, while for bacteria, 15 pairs of data were compared. Data for the north basin (St. Ie) are from Naciata (1988).

(2) C.V., coefficient of variation $(\%)$.

IsHIDA, 1985) may also utilize bacterial resources.

Finally we discuss vertical distribution of heterotrophic microbes at St. D. In the anoxic layer, flagellates and bacteria were larger in size than in the oxic layer (Fig. 4), suggesting that morphologically distinct microbes exist in the anoxic layer (Pedrós-Alió and Brock, 1982). An outstanding trend of the vertical distribution pattern of flagellates was the maxima of abundance at a depth of 6 m on 9 August and 18 September. This depth was the oxic-anoxic boundary layer (August), or the bottom of the oxic layer (September). Sorokis (1965) has proposed that, in stratified water column with the anoxic hypolimnion, the supply of reduced compounds from the anoxic layer enhances chemosynthetic activity of bacteria at the oxic anoxic interface, and that the density of protozoans is highest in this layer. More recently, maxima of bacterial cell density, heterotrophic activity (incorporation rate of leucine) of bacteria, and cell density of bacterivorous protozoans (scuticociliates) were found in the oxic-anoxic boundary of the stratified Lake Oglethorpe (PACE, 1982 ; McDonoc(in et al., 1986). Although the maximum of bacterial density in the oxic-anoxic boundary layer was not found at St. D in Lake Biwa (Fig. 4), it was considered that bacterial activity would be the highest in this layer, because higher flagellate activity may enhance bacterial activity (SIEBLRTI and DAVIs, 1982), and the subsurface maxima of the flagellates were found in the present study (Fig. 4). However, movement of water and grazing activity of larger suspension feeders may also affect the vertical distribution pattern of heterotrophic microbes in a complex manner. Therefore, in order to assess the validity of the above hypothesis, research on the vertical distribution of the activity of flagellates and bacteria is needed.

\section{Acknowledgments}

The author is grateful to Prof. Y. Trzuki of Kyoto Univ. for comments on the manuscript. Thanks are also due to other researchers of Otsu Hydrobiological Station, Kyoto Univ. for discussions. This study was partly supported by Grant 61790227 for Scientific Research from the Ministry of Education, Science and Culture of Japan.

\section{摘 要}

\section{琵琶湖南湖における従属栄養性小型鞭毛虫の} 季節的消長，細菌に対する摂食影響，および垂直分布

1984 年の 5 月から 10 月までの間, 富栄養水域であ る琵琶湖南湖湖心部の定点 (水深約 $4 \mathrm{~m}$ ) に扔いて, 従 属栄養性小型鞭毛虫と細菌の細胞数の季節变動在調査 した。鞭毛虫と細菌の細胞数は，そ扎ぞれ，1.7×10 ${ }^{3}$ $9.7 \times 10^{3}$ cells・ml $\mathrm{ml}^{-1}$ ，执よび $2.5 \times 10^{6}-1.5 \times 10^{7}$ cells . $\mathrm{ml}^{-1}$ の範囲で変動した。細菌に対する鞭毛虫ひ瞬間摂 食速度を鞭毛虫の現存量か的推定したところ, 0.003-0.020 $\mathrm{hr}^{-1}$ の範囲の值示し, 一方, 分裂細胞 頻度から推定した細菌の瞬間増殖速度は 0.009-0.034 $\mathrm{hr}^{-1}$ の範囲の值を示した。これらのデータから，1日 当たりの細菌生産量の 13-130\%は鞭毛虫によって消 費されているものと推定された。次に，しゅんせつ跡 地 (水深約 $12 \mathrm{~m}$ ) に㧈いて鞭毛虫の垂直分布在調べた ところ,成層期には細胞数の亜表水層極大が見られた。 細菌消費者としての鞭毛虫の重要性や富栄養水体に抽 ける鞭毛虫出現の特徽について考察を加えた。

\section{References}

Azalı, F., T. Fenched, J. G.Find, J. S. Gray, L. A. Meyer reil and F. Thingistal (1983) : The ecological role of water-column microbes in the sea. Mar. Ecol. Prog. Ser., 10 : 257-263.

Boxidan, K. G., J. J. GILBERT and P. L. STARKWEATHER (1980): In situ clearance rates of planktonic rotifers. Hydrobiologia, 73 : 


\section{3-77.}

Fenchel, T. (1980) : Suspension feeding in ciliated protozoa : Functional response and particle size selection. Microb. Ecol., $6: 1-11$.

Ffinchel, T. (1982a) : Ecology of heterotrophic microflagellates. I . Some important forms and their functional morphology. Mar. Ecol. Prog. Ser., $8: 211-223$.

Fexchel, T. (1982b) : Ecology of heterotrophic microflagellates. II. Bioenergetics and growth. Mar. Ecol. Prog. Ser., 8 : 225-231.

Fexchel, T. (1982c) : Ecology of heterotrophic microflagellates. IV. Quantitative occurrence and importance as bacterial consumers. Mar. Ecol. Prog. Ser., 9 : 35-42.

Fenchel, T. (1987) : Ecology of protozoa: The biology of free-living phagotrophic protisits. Science Tech Publishers.

Fexcehl, T. and J. Finlay (1983) : Respiration rates in heterotrophic, free-living protozoa. Microb. Ecol., 9 : 99-122.

GiDE, H. (1986) : Loss processes influencing growth of planktonic bacterial populations in Lake Constance. J. Plankton Res., 8 : 795-810.

Haciströ̀, Å., U. Larsson, P. Hörstedt and S. NoR.MARK (1979) : Frequency of dividing cells, a new approach to the determination of bacterial growth rates in aquatic environments. Appl. Environ. Microbiol., 37 : 805 812.

Hobbie, J. E., R. J. DAlEy and S. JAsper (1977) : Use of Nuclepore filters for counting bacteria by fluorescence microscopy. Appl. Environ. Microbiol., 33 : 1225-1228.

Kinura, B. and Y. Ishidd (1985) : Photophagotrophy in Uroglena americana, Chrysophyceae. Jpn. J. Limnol., 46 : 315-318.

McDonolgh, R. J., R. W. Sanders, K. G. Porter and D. L. Kirchuax (1986) : Depth distribution of bacterial production in a stratified lake with an anoxic hypolimnion. Appl. Environ. Microbiol., 52 : 992-1000.

NAciATA, T. (1984): Bacterioplankton in Lake Biwa : Annual fluctuations of bacterial numbers and their possible relationship with environmental variables. Jpn. J. Limnol., 45 : 126-133.

NAciatA, T. (1985) : Filter mesh-sizes of Daphnia longispina and its filtering rates on natural bacteria. Mem. Fac. Sci., Kyoto Univ. Ser. Biol., 10 : 109-114.
NAGitA, T. (1986a) : Carbon and nitrogen content of natural planktonic bacteria. Appl. Environ. Microbiol., $52: 28-32$.

NAciatA, T. (1986b) : The seasonal abundance and vertical distribution of the $\langle 3-\mu \mathrm{m}$ phytoplankton in the north basin of Lake Biwa. Ecol. Res. 1 : 207-221.

NAciata, T. (1987) : Production rate of planktonic bacteria in the north basin of Lake Biwa, Japan. Appl. Environ. Microbiol., 53 : 28722882.

NAcita, T. (1988) : The microflagellate-picoplankton food linkage in the water column of the north basin of Lake Biwa. Limnol. Oceanogr., 33 : 504-517.

NAGATA, T. and K. OKanoTo (1988) : Filtering rates on natural bacteria by Daphnia longispina and Eodiaptomus japonicus in Lake Biwa. J. Plankton Res., 10 : 835-850.

PAcE, M. L. (1982) : Planktonic ciliates : their distribution, abundance, and relationship to microbial resources in a monomictic lake. Can. J. Fish. Aquat. Sci., 39 : 1106-1116.

PenRós-Alı́, C. and T. D. Brock (1982) : Assessing biomass and production of bacteria in eutrophic Lake Mendota, Wisconsin. Appl. Environ. Microbiol., 44 : 203-218.

RIIMAN.N, B. (1985) : Potential importance of fish predation and zooplankton grazing on natural populations of freshwater bacteria. Appl. Environ. Microbiol., 50:187-193.

SANiners, R. W. and K. G. Porter (1986) : Use of metabolic inhibitors to estimate protozooplankton grazing and bacterial production in a monomictic eutrophic lake with an anaerobic hypolimnion. Appl. Environ. Microbiol., 52 : 101107

SCAIAA, D. and G. A. LAIRI) (1987) : Bacterioplankton in Lake Michigan : Dynamics, controls, and significance to carbon flux. Limnol. Oceanogr., 32 : 1017-1033.

Sherr, E. B. and B. F. Sherr (1983) : Doublestaining epifluorescence technique to assess frequency of dividing cells and bacteriovory in natural populations of heterotrophic microprotozoa. Appl. Environ. Microbiol., 46 : 1388- 1393.

Sherr, E. B. and B. F. Sherr (1987) : High rates of consumption of bacteria by pelagic ciliates. Nature, 325: 710-711.

Sherr, B. F., E. B. Sherr and T. BermaN (1983) : 
Grazing, growth, and ammonium excretion rates of a heterotrophic microflagellate fed with four species of bacteria. Appl. Environ. Microbiol., 45 : 1196-1201.

Sherr, B. F., E. B. Sherr and S. Y. Newell (1984): Abundance and productivity of heterotrophic nanoplankton in Georgia coastal waters. J. Plakton Res., 6 : 195-202.

Sieburth, J. McN. and P. G. Davis (1982) : The role of heterotrophic nanoplankton in the grazing and nurturing of planktonic bacteria in the Sargasso and Caribbean seas. Ann. Inst. Océanogr., Paris, 58 : 285-296.

Sorokin, Ju. I. (1965) : On the trophic role of chemosynthesis and bacterial biosynthesis in water bodies. Mem. Ist. Ital. Idrobiol., 18 (Suppl.) : 187-205.

Strickland, J. D. H. and T. R. PArsoNs (1972) : A practical handbook of seawater analysis, 2nd ed. Bull. Fish. Res. Bd. Can. (Bulletin no.167)

Terashima, A. and T. Ueda (1982) : Effects of bottom dredging on some environmental factors and benthic animals in the south basin of Lake Biwa. Jpn. J. Limol., 43 : 81-87. (in Japanese)

TezukA, Y. (1984) : Seasonal variations of dominant phytoplankton, chlorophyll $a$ and nutrient levels in the pelagic regions of Lake Biwa. Jpn. J. Limnol., 45 : 26-37.

Wright, R. T. and R. B. Coffin (1984) : Measuring microzooplankton grazing on planktonic marine bacteria by its impact on bacterial production. Microb. Ecol., 10 : 137-149.

(著者: 永田 俊, 京都大学理学部付属大津臨湖実 験所, 干 520-01大津市下阪本 4-1-23：Toshi Nagiata, Otsu Hydrobiological Station, Kyoto University, Shimosakamoto, Otsu, 520-01)

Received : 12 Febmary 1988 Accepted : 11 April 1988 